Vol. 15, n² | 2011

Varia

\title{
American Homicide. What Does the Evidence Mean for Theories of Violence and Society?
}

Pieter Spierenburg

\section{(2) OpenEdition}

Electronic version

URL: https://journals.openedition.org/chs/1295

DOI: $10.4000 /$ chs. 1295

ISSN: 1663-4837

Publisher

Librairie Droz

Printed version

Date of publication: 1 December 2011

Number of pages: 123-129

ISSN: 1422-0857

\section{Electronic reference}

Pieter Spierenburg, "American Homicide. What Does the Evidence Mean for Theories of Violence and Society?", Crime, Histoire \& Sociétés / Crime, History \& Societies [Online], Vol. 15, n² I 2011, Online since 01 December 2014, connection on 23 March 2022. URL: http://journals.openedition.org/chs/1295 ; DOl: https://doi.org/10.4000/chs.1295 


\title{
American Homicide ${ }^{1}$ What Does the Evidence Mean for Theories of Violence and Society?
}

\author{
Pieter Spierenburg
}

Randolph Roth's American Homicide is an impressive book which has been long awaited among specialists in historical violence ${ }^{2}$. It is based on an enormous research effort matched only by the amount of reading in secondary literature that has gone into this study. Even historians disagreeing with Roth's overall thesis will learn much about American history or, for example about the character and circumstances of intimate homicide. All in all, his quantitative evidence, covering much of the territory of the present United States, represents a gigantic step forward compared to the amount of the data hitherto available. This is a stimulating book that offers much for scholars to engage with. Surely, the debate in this issue of CHS will not end the discussion. And I wish to emphasise that I mean all this, before I proceed to the inevitable critical questions.

Roth's thesis appears to parallel that of Gary LaFree. The latter found a surprisingly neat negative correlation between the annual homicide level in the United States and the percentage of Americans who said they trusted the government to do what is right and an equally neat positive correlation with the proportion of Americans who believed that quite a few government officials are crooked. These correlations have been observed roughly from 1960 to $2000^{3}$. Hence, trust in government makes people less homicidal. Whether Roth developed his parallel thesis after reading LaFree or independently from him hardly matters. Roth's book reads as an extension of LaFree's thesis all the way back to the seventeenth century. The trustin-government explanation serves to make sense of what seems, at first sight, a bewildering pattern of increases in homicide in one place and decreases in another. It is not a confusing pattern at all, Roth concludes, because in all instances the rates went down when and where trust in government or the sense of national unity went up and vice versa. Moreover, he does not merely present this as an additional explanation for short- or middle-term fluctuations in the homicide level. In Roth's view, his findings present a challenge to Norbert Elias' theory of civilizing processes, which up to now holds sway among scholars dealing with long-term developments in violence.

As I have no new data of my own on American homicide, my aim here is not to « disprove» Roth's thesis. I just want to ask a few questions and express some doubt that may lead the subject to being viewed from another angle. Because Roth's

The manuscript of this article has been sent to the editors of CHS on 23 September 2010. It refers to Randolph Roth's website as of that date.

2 Radolph Roth, American homicide, Cambridge, MA., 2009.

3 See the tables, based largely on LaFree, in Roth (2009, pp. 450-451). 
evidence and his theory are closely related, as they should be, my questions pertain to both. I will first examine his method, proceeding with a fresh look at the empirical picture emerging from his counts. Next, I will discuss the implication of that examination for his thesis: is there room for alternative explanations? Finally, I will present some general reflections about Elias' theory and historical interpretations of homicide. In this effort it is inevitable to take Roth's website into account, to which he frequently refers in the book ${ }^{4}$.

The method is undoubtedly refined. It is based on the capture-recapture principle first advocated for estimating the incidence of homicide by Eric Monkkonen ${ }^{5}$. The method in question was originally developed to make estimates in the present such as the number of deer in a forest: You capture and mark them and at the second capture you observe which percentage of the deer is marked. Understandably, this procedure can only be applied to the past if the two captures have already been made. It means that the researcher needs to find two series listing homicides for the same period, which must have been compiled independently from each other. The prototypical examples, in American history, are court records and newspapers. Based on the overlaps between the two series, the investigator can estimate the number of cases missed by both. It is fortunate that the abundance of sources in American archives often makes capture-recapture possible, but to what extent does Roth inform the reader about the exact nature of these sources?

The chapters of the book restrict themselves to a discussion of the results of his estimates and calculations. They contain numerous tables and graphs showing homicide rates without information on the population figures or the sources for counting the homicides. The book's two appendices provide a brief overview of the principal sources involved, organized according to regions, and an equally brief outline of the calculations. Critical readers are obliged to turn to Roth's website, where the file «Homicide Estimates» is the only one revealing the sources for his calculations. To the reader's surprise, however, this file distinguishes only between «legal» and «other» sources. The legal category combines the reliable source of coroner's records or body inspection reports and the highly unreliable source of indictments or just prosecuted homicide (the «rule» in the book's appendix that indictments always represent about $50 \%$ of all homicides seems to me a bit too confidently stated). The other category includes not only newspapers but also diaries and local histories; the latter two appear more selective to me. This relative lack of detail about the nature of the sources leaves us with some doubt about the reliability of the estimates.

Of course we already knew that the communities of voluntary and forced migrants who gradually wrestled the territory of the present US from the Indians since the early seventeenth century had a history with respect to homicide that differed from the European patterns of long-term decline from the middle ages to about

4 [http ://cjrc.osu.edu/researchprojects/hvd/AHsup.html] (accessed 17 September, 2010). The website includes a file «Responses to Misunderstandings by Reviewers» (dated 1. August 2010), so the debate will probably have caught up with some of my remarks by the time that this issue of CHS reaches the reader.

5 Eric Monkkonen, New standards for historical homicide research, Crime, Histoire \& Sociétés/ Crime, History \& Societies, 2001, 5, 2, pp. 7-26. See also Bruno Aubusson's comments in the same issue. 
1970. Nevertheless, most crime historians used to believe that American history, too, witnessed some modest decline of homicide on average. In this perspective, Roth's evidence reveals two remarkable episodes of prolonged low homicide rates; that is, when we might have expected them to be higher or not yet to have decreased so much. These occurred in the Colonies from the late seventeenth century to the Revolution and again in the Northern states and the mountain South between c. 1810 and c. 1850. The first period of low levels of homicide extended over nearly all of what was then (non-native) America, but could it have something to do with the sources? From «Homicide Estimates» we learn that the «other» category of sources predominates only at the very beginning of each colony's history when the incidence of homicide was high anyway. Moreover, from the book's first appendix we learn that although some newspapers are quite old, on average the series of extant newspapers begins in the Revolutionary period. Hence the period of low levels of homicide in the Colonial era coincides with a time when generally speaking no newspapers are available and legal sources predominate. Could it be that in most cases these legal sources are mainly indictments and that, consequently, the low homicide rates are partly due to underestimation ${ }^{6}$ ? Without the information we cannot tell. If so, this would leave us only with the other remarkable low point, which of course was merely regional.

Especially for the nineteenth century there is another conspicuous feature. In Roth's graphs the homicide rates jump up and down in neat blocks. In Gilmer and Rebun counties, Georgia (p. 199, figure 5.5), for example, they start at 20 between 1828 and 1840, then fall to about 2 for most of the 1840s, jump to about 25 for the next eight years or so, fall back to 2 between 1855 and 1865, then climb to no less than 55 for about five years, after which they fluctuate between about 28 and about 14 (the "abouts" are due to the necessity to estimate the distances in the graph). In each period these are of course average annual rates, but could it be that the absolute numbers involved are so low that the variation is just accidental? I have searched for Georgia in the relevant files on Roth's website, but I have been unable to find either the absolute numbers or the population figures for these two counties. According to table 8 of the file «Homicide Estimates », the average absolute number of estimated homicides in three other Georgian counties together during four periods stretching from 1790 to 1887 fluctuated between two and seven per year. That gives pause for thought. The historian Robert Dykstra has been most adamant in rejecting homicide rates calculated for very small populations ${ }^{7}$. I disagree with him to the extent that, when high rates are found consistently for related places such as medieval cities, we may take these places together. To the extent that Roth disaggregates the rates to the level of small counties I must agree with Dykstra.

For my part, I would have liked to see some attempt to reconstruct national rates, which are absent until the $1930 \mathrm{~s}^{8}$. Roth has his reasons to disaggregate the rates. His tables contain all kind of labels, such as Mexican War, Union Victory or Agrarian

6 Significantly, Roth also refers to Jack D. Marietta \& G.S. Rowe, Violent crime, victims and society in Pennsylvania, 1682-1800, Explorations in Early American Culture, 1999, 66, pp. 24-54. I have always discarded the homicide rates in this article because they are based on indictments only.

7 See among others, Robert R. Dykstra, Body counts and murder rates. The contested statistics of Western violence, Reviews in American History, 2003, 31, pp. 554-563.

8 Consider also the graph for seven cities (p. 185): why not combine them? 
Crisis, that are meant to underline his trust-in-government thesis. And these turning points can have different effects in different places. Thus, the label KansasNebraska Act marks a huge drop in homicide in the two Georgian counties mentioned, but it stands at a spot where a peak begins in a county in Illinois (p. 184). The Kansas-Nebraska Act, which in 1854 determined that settlers in each new state could decide for themselves whether or not they would have slavery, apparently made Southerners less homicidal, because the act had been designed by a Democrat, and Northerners more homicidal, even though the Democrat was from Illinois. Obviously, national feeling and trust in government do not only vary over time but also per place and even for different groups in the population. Hence there are tables for whites in one county, Chinese in another, etc. Roth is required by his thesis to disaggregate the homicide rates. In a graph of aggregated national rates the presumed effect of the Kansas-Nebraska Act would completely disappear.

With so much doubt remaining, the question whether Roth's labels accurately represent the principal turning points in national feeling is perhaps less relevant. Yet a reference to the point made by Jill Lepore is pertinent here 9 . She emphasizes that there are no opinion surveys from before 1958, the first year examined by LaFree. Hence Roth must find and define trust in government himself and we may ask whether this has been tailored to the homicide curves. In other words, could we identify still other significant political events, not mentioned in Roth's tables because they don't coincide with turning points in the homicide rates ${ }^{10}$ ?

My final methodological criticism concerns the fact that Roth consistently relates the number of homicides not to the total population but to the adult population only. This procedure artificially raises the homicide rate. Furthermore, most of his graphs and tables refer only to homicides among unrelated adults, which lowers the rates again. Of course a separate examination of family or intimate murders is legitimate and necessary, but we first need the overall rates. We cannot assume that the two exercises of raising and lowering these rates even out. All this makes it difficult to compare Roth's data with those in other studies of homicide.

Many of these studies concern Europe and Roth attempts to bolster his theory with a new view of that continent. In the book's introductory chapter (p. 23) he states that European nations and the United States went different ways by the late nineteenth century: European populations grew ever more peaceful while America turned homicidal. "No wonder", he adds. The USA had just experienced the Civil War and afterwards the country remained a divided nation; in Europe, by contrast, Italy and Germany had just become nations and everything was alright in the other countries too. However, why couldn't Roth's theory require the opposite evidence? In that case, we would emphasize that European countries experienced the divisive effects of socialism, whereas socialism failed to take root in America. Hence homicide rates actually should have gone up in Europe and down in the US. In Roth's thesis it is always about stability and trust as a nation; trust between social classes doesn't count. A passage in the book and a file on his website reveal that he believes his thesis to be valid even for Europe. I will not take this up at present. Let me just point out that the claim «In Leiden the [homicide] rate rose to 30 per 100,000 adults per

\footnotetext{
9 Jill Lepore, Rap sheet. Why is American history so murderous?, The New Yorker, 9 November 2009.
}

10 Roth's brief reply in «Responses to Misunderstandings by Reviewers» is not very convincing. 
year after 1801, when Napoleon imposed an authoritarian government on the Netherlands » (p. 146) is completely untrue ${ }^{11}$.

So let me discuss the merits of Roth's thesis and an Elias-based alternative for America only. In his full statement of his argument (p. 18) Roth identifies four sets of beliefs and feelings that keep homicide rates down. «(1) The belief that government is stable and that its legal and judicial institutions are unbiased and will redress wrongs and protect lives and property. (2) A feeling of trust in government and the officials who run it and a belief in their legitimacy. (3) Patriotism, empathy and fellow feeling arising from racial, religious or political solidarity. (4) The belief that the social hierarchy is legitimate, that one's position in society is or can be satisfactory and that one can command the respect of others without resorting to violence ». Roth calls these factors «closely related». It is unclear whether they are also meant as cumulative. In that case the phrase at the very end would be crucial and the whole argument circular: the incidence of homicide is low when people believe they can do without violence. Presumably, that is not the way Roth wants his thesis to be interpreted. The first factor, on the other hand, reveals that this thesis is not entirely antithetical to Elias' theory. According to Roth, the first factor operates especially «on contested frontiers and during revolutions, civil wars and military occupations » (p. 18) or in other words when a stable state system is absent. This is of course in line with Elias, who posits that civilizing processes, including the taming of aggressive urges, are related to processes of state formation.

Roth has various passages confirming this relationship: «... the lack of stable government was what truly opened the floodgates to a torrent of murders » (p. 156); «homicide rates declined as soon as ... a stronger national government emerged» (p. 183); «high homicide rates [when] ... there was no stable, legitimate government» (p. 356). Even more telling are the two graphs (figures 1.2 and 1.3 on pp. 3839) that show a sharp decline in homicides in New England, Maryland and Virginia during the seventeenth century. Compared with this decline, the fluctuations after 1700 appear insignificant.

Admittedly, I suggested above that the late-Colonial rates might be underestimated, but regardless of whether they are or not, another question is pressing. At which point of societal development can we consider the murder rate as indicative for the overall level of violence and aggression in a society? In my view, we should do this only for societies in which it is possible to distinguish clearly between interpersonal violence and state violence ${ }^{12}$. Furthermore, in a passage in an article written in reaction to the views of Eric Monkkonen on American homicide I expressed doubts about the possibility of making this distinction for the Colonial period ${ }^{13}$. Its

11 Although the remark about Napoleon is highly questionable as well, I mean the alleged homicide rate. Roth refers to two articles by Herman Diederiks, of which the first says nothing at all about homicide. The other (Quality and quantity in historical research in criminality and criminal justice. The case of Leiden in the $17^{\text {th }}$ and $18^{\text {th }}$ centuries, Historical Social Research/ Historische Sozialforschung, 1990, 15, 4, pp. 57-76) has data only for homicide trials, which steadily went down since 1600. Roth probably mistakenly took his figure from Diederiks' graph with all offenses sentenced.

12 See the introduction to Pieter Spierenburg, A history of murder. Personal violence in Europe from the middle ages to the present, Cambridge, Polity Press, 2008.

13 Eric Monkkonen, Homicide: Explaining America's exceptionalism, American Historical Review, 2006, 111, 1, pp. 76-94; Pieter Spierenburg, Democracy Came Too Early: A Tentative Explanation for the Problem of American Homicide, American Historical Review, 2006, 111, 1, pp. 104-114. 
white-on-white homicide rate may have been low at times, but Colonial AngloSaxons were obliged to be on their guard constantly and to rely on their own strength each time when confronted with attacking Indians, French colonial competitors or rebellious slaves. In such a situation the dividing line between murder and military action is very thin. According to Elias' theory (and in line with the historical evidence) it is only when processes of state formation have led to the existence of a larger space that is relatively pacified that we can consider the incidence of murder (each one an encroachment upon the state's monopoly of violence) as indicative for the level of personal aggression within that space. Roth chooses to ignore Monkkonen's article and the reactions to it, published in 2006. In my view, explaining the level of personal aggression and, with it, the nature of civilizing processes and their relationship to other social processes such as state formation lies at a higher theoretical level than just explaining the number of homicides however defined.

This also means that theoretical considerations always require rigorously separating state violence from interpersonal violence. Hence, police killings should never be included in the homicide rate, regardless of whether they are considered justified or prosecuted as unlawful. On this point, too, Roth and I disagree. Of course, apart from the homicide rate, state violence can be studied and even measured to some extent. We can establish the per capita rate of executions in a country or the number of soldiers killed in the trenches during World War I, for example, or indeed the number of persons shot by police. Usually, in the course of processes that involve civilizing tendencies as well as the diminution of power differentials between social groups, increasing demands are made on state agencies for moderation in using their monopoly of force for internal peace-keeping. Up to now this applies much less to the external use of violence.

In applying Elias' theory to the United States, Stephen Mennell's The American Civilizing Process is an invaluable guide. Perhaps Roth cannot be blamed for failing to refer to this book either, since it appeared only two years prior to his. For one thing, as is common among scholars working with Elias' theory, Mennell carefully distinguishes between «civilization» as a scholarly concept and «civilization» as a value in the public debate. He analyzes the latter, «involved» uses of the term by the founding fathers and in reactions to $9 / 11$. When Roth refers to «civilization» he often appears to confuse the two applications of the term. Next, Mennell attaches great significance to the fact that the United States never had the experience of one single model-setting elite - again a thesis that could have enriched Roth's analysis.

Finally, in order to explain the persistence of relatively high homicide rates in the United States, Mennell adopts my democracy-came-too-early thesis that I developed in the discussion with Eric Monkkonen, just referred to. Of course, the slogan that "democracy came too early" is a rhetorical statement, highlighting the different pace of historical developments on either side of the Atlantic. In Europe it took centuries, marked by recurrent setbacks, before stable monopolies of force were established. At some point, resistance to the royal monopoly shifted from trying to destroy it to trying to co-possess it. In the latter case, the people were accustomed to being disarmed in day-to-day affairs; they accepted the monopoly as such but wished to have a say in how it was used. On the American continent, on the other hand, democracy was introduced before the people had got accustomed to being disarmed (from whatever weapons). Consequently, an ethic of self-help and distrust in state agencies remain widespread among Americans. This does not mean that a monopoly of force did not emerge at all, which would fly in the face of the evidence. 
It means that there remain strong counter-tendencies to its full effectuation. In my view, that may explain the persistence of high homicide rates, relative to Western and Central Europe, for much of US history.

I still regard it worthwhile to further investigate this thesis and Roth's book would be an enormous help in that enterprise. As said earlier, I merely put questions to some of his data and do not wish to contest them outright. Obviously, the persistence of high homicide rates has not occurred always and everywhere since the Revolution. Only an indirect relationship can be established between lower levels of effectuation of the monopoly of force and higher murder rates and we need more knowledge about the intermediate factors.

Pieter Spierenburg Erasmus University Rotterdam spierenburg@law.eur.nl 